Relations industrielles

Industrial Relations

\title{
The Minimum Wages in the Building Industry
}

\section{Gérard Roy}

Volume 4, numéro 4, décembre 1948

URI : https://id.erudit.org/iderudit/1023460ar

DOI : https://doi.org/10.7202/1023460ar

Aller au sommaire du numéro

Éditeur(s)

Département des relations industrielles de l'Université Laval

ISSN

0034-379X (imprimé)

1703-8138 (numérique)

Découvrir la revue

Citer cet article

Roy, G. (1948). The Minimum Wages in the Building Industry. Relations

industrielles / Industrial Relations, 4(4), 36-38. https://doi.org/10.7202/1023460ar

Tous droits réservés @ C Département des relations industrielles de l’Université Laval, 1948
Ce document est protégé par la loi sur le droit d'auteur. L'utilisation des services d'Érudit (y compris la reproduction) est assujettie à sa politique d'utilisation que vous pouvez consulter en ligne.

https://apropos.erudit.org/fr/usagers/politique-dutilisation/ 
was inserted in the law it aimed at permitting the extension of all the clauses of a collective agreement which could apply to a business or an industry. It was only following legal opinions that this clause was given the restricted scope which we know at the present.

What is important to-day is not to make the most of the reasons for limiting the field of action of the law but to study, to search for and to find the means of extending it to the whole domain and to all the problems of employer-employee relationships.

It would be advisable, in the third place, that the same facilities be accorded to those who wish to negotiate in virtue of the Collective Agreement Act as to those who wish to negotiate in virtue of the Labour Relations Act. In other words, it is necessary that the contracting parties be assured the facilities of conciliation and arbitration for the negotiating of contracts but more, when the decree is in force, that the disputes should be submitted to a Labour Tribunal capable of regulating problems expeditiously and without the complications and delays of our courts of justice.
To resume, if we wish the Collective Agreement Act to continue to play its part, if we wish that it should not decline but progress, it must evolve, it must be reinforced where its opponents are finding weak points, it must be amended from the results of experience. Then the contracting parties will find it to their interest to negotiate in virtue of this law in preference to all others and it would benefit from all the advantages of the existing laws as well for the negotiating of decrees as for the putting of them into effect.

The Bulletin of Industrial Relations spreads abroad both principles and facts. Nothing prevents it, from my way of thinking, from presenting also opinions or submitting subjects for study. It could be that I am wrong, but I fear that if the Collective Agreement Act is confined in limits too narrow to respond to actual needs, it will be abandoned in spite of all the services which it does and could render. This law was erected on a marvellous principle. It is our business to see that it is given the opportunity to operate.

\title{
THE MINIMUM WAGES IN THE BUILDING INDUSTRY
}

\author{
GÉraRd RoY
}

In most of the regions of the Province the working conditions of labour in the construction trades are now regulated by decrees put into effect under the Collective Agreement Act. After fifteen years of the Law's application in this field it is most interesting to analyse the 84 basic decrees passed since 1934 and the 335 Orders in Council amending them, with a view to deriving therefrom statistics extremely useful to employeremployee organizations, to the parity committees entrusted with the supervision and carrying out of the decrees, and to all those who are interested in the problems of industrial relations.

The following tables dealing with the trades of joiner-carpenter, electrician and bricklayer give a general idea of the minimum wages set by the decrees since 1934 in the principal regions of the Province.
According to the Federal Bureau of Statistics the most recent cost of living index, November 1948 , stands at 159.6. The comparison between the increase of the cost of living and the rise in the scale of wages can be made for each region. Nevertheless, before drawing definite conclusions from these figures we must take certain factors into consideration - the real level of the cost of living, certain wage levels which were not high enough in 1939, the strength of labour organizations etc., etc.

It is most important to underline the fact that minimum wages (made obligatory by law) not being subject to the fluctuations of the Law of Supply and Demand, are a guarantee for the workman. However, in many regions, the real wage is often higher than the minimum rate of the decree because of individual arrangements resulting from the unprecedented period of activity in which the building industry finds itself. 
TABLE 1: MINIMUM WAGES FOR THE TRADE OF CARPENTER-JOINER IN THE PROVINCE OF QUEBEC 1934-1948 ${ }^{1}$

\begin{tabular}{|c|c|c|c|c|c|c|c|c|c|c|c|c|c|c|c|c|}
\hline DISTRICTS & 1934 & 1935 & 1936 & 1937 & 1938 & 1939 & 1940 & 1941 & 1942 & 1943 & 1944 & 1945 & 1946 & 1947 & 1948 & $\begin{array}{l}\text { Absolute } \\
\text { increase }\end{array}$ \\
\hline Abitibi * & $\ldots$ & $\ldots$ & $\ldots$ & $\ldots$ & $\ldots$ & $\cdots$ & $\cdots$ & .55 & .55 & .55 & .60 & .60 & .85 & .90 & 1.00 & .45 \\
\hline Hull & $\ldots$ & .65 & .65 & .65 & .80 & .80 & .80 & .85 & .85 & .90 & .90 & .95 & 1.05 & 1.05 & 1.15 & .35 \\
\hline Montréal & .60 & .60 & .60 & .70 & .70 & .70 & .77 & .81 & .86 & .86 & .95 & .96 & 1.06 & 1.06 & 1.25 & .55 \\
\hline Québec & .50 & .50 & .50 & .55 & .55 & .55 & .60 & .65 & .70 & .70 & .80 & .80 & .90 & .95 & 1.00 & .45 \\
\hline Saint-Hyacinthe & $\ldots$ & .35 & .35 & .40 & .50 & .50 & .50 & .55 & .55 & $.621 / 2$ & .70 & .70 & .80 & .85 & .90 & .40 \\
\hline Saint-Jean & $\ldots$ & $\ldots$ & $\ldots$ & $\ldots$ & .50 & .50 & .55 & .55 & .63 & .63 & .63 & .70 & .80 & .85 & .90 & .40 \\
\hline Sorel & $\cdots$ & $\ldots$ & $\ldots$ & .50 & .50 & .50 & .50 & .50 & .50 & .55 & .65 & .65 & .85 & 1.00 & 1.00 & .50 \\
\hline Terrebonne $\ldots \ldots \ldots$ & $\ldots$ & $\cdots$ & $\cdots$ & $\cdots$ & $\cdots$ & .50 & .60 & .65 & .70 & .70 & .75 & .75 & .85 & .85 & .95 & .45 \\
\hline Trois-Rivières & $\ldots$ & .55 & .55 & .55 & .55 & .55 & .60 & .65 & .70 & .75 & .75 & .75 & .80 & .90 & 1.00 & .45 \\
\hline
\end{tabular}

(1) Decrees pursuant to the Collective Agreement Act. In the regions comprising more than one zone the rates mentioned are those of Zone I.

TABLE 2: MINIMUM WAGES FOR THE TRADE OF ELECTRICIAN IN THE PROVINCE OF QUEBEC 1934-1948 1

\begin{tabular}{|c|c|c|c|c|c|c|c|c|c|c|c|c|c|c|c|c|}
\hline DISTRICTS & 1934 & 1935 & 1936 & 1937 & 1938 & 1939 & 1940 & 1941 & 1942 & 1943 & 1944 & 1945 & 1946 & 1947 & 1948 & $\begin{array}{l}\text { Absolute } \\
\text { increase }\end{array}$ \\
\hline Chicoutimi & $\ldots$ & $\ldots$ & .50 & .50 & .50 & .50 & .55 & .60 & .65 & .65 & .65 & .75 & .85 & .90 & 1.00 & .50 \\
\hline Abitibi * & $\ldots$ & $\cdots$ & $\cdots$ & $\cdots$ & $\cdots$ & $\cdots$ & $\cdots$ & .65 & .65 & .65 & .70 & .70 & .85 & .90 & 1.00 & .35 \\
\hline Hull & $\cdots$ & .70 & .70 & .70 & .70 & .70 & .70 & .70 & .70 & .75 & .75 & .75 & 1.05 & 1.05 & 1.05 & .35 \\
\hline Joliette & .45 & .45 & .45 & .45 & .50 & .50 & .50 & .50 & .50 & .55 & .75 & .75 & .85 & .90 & 1.05 & .55 \\
\hline Montreal & .65 & .65 & .65 & .75 & .75 & .75 & .83 & .87 & .92 & .92 & 1.00 & 1.01 & 1.11 & 1.11 & 1.35 & .60 \\
\hline Québec & .45 & .45 & .45 & .50 & .55 & .55 & .60 & .65 & .70 & .70 & .80 & .80 & .90 & .95 & 1.00 & .45 \\
\hline Saint-Hyacinthe & $\ldots$ & .35 & .35 & .45 & .45 & .45 & .45 & .50 & .50 & $.571 / 2$ & .65 & .65 & .75 & .85 & .90 & .45 \\
\hline Saint-Jean & $\ldots$ & $\ldots$ & $\ldots$ & $\ldots$ & .55 & .55 & .60 & .60 & .68 & .68 & .68 & .73 & .83 & .90 & 1.00 & .45 \\
\hline Sherbrooke & $\ldots$ & $\ldots$ & .50 & .50 & .55 & .55 & .60 & .60 & .60 & .65 & .65 & .75 & .75 & .85 & .95 & .40 \\
\hline Drummond $\ddagger$ & $\cdots$ & .50 & .50 & .50 & .50 & .50 & .55 & .55 & .55 & .60 & .60 & .70 & .70 & .80 & .90 & .40 \\
\hline Sorel & $\ldots$ & $\cdots$ & $\ldots$ & .50 & .50 & .50 & .50 & .50 & .50 & .55 & .65 & .65 & .85 & 1.00 & 1.00 & .50 \\
\hline Terrebonne & $\ldots$ & $\cdots$ & $\cdots$ & $\cdots$ & $\cdots$ & .60 & .60 & .60 & .65 & .65 & .80 & .80 & .90 & .90 & 1.00 & .40 \\
\hline Trois-Rivières & .45 & .45 & .45 & .45 & .50 & .50 & .55 & .60 & .65 & .70 & .70 & .70 & .75 & .90 & 1.00 & .50 \\
\hline
\end{tabular}

(1) Decrees pursuant to the Collective Agreement Act. In the regions comprising more than one zone the rates mentioned are those of Zone $I$. 
TABLE 3: MINIMUM WAGES FOR THE TRADE OF BRICKLAYER IN THE PROVINCE OF QUEBEC 1934-1948 ${ }^{1}$

\begin{tabular}{|c|c|c|c|c|c|c|c|c|c|c|c|c|c|c|c|c|}
\hline DISTRICTS & 1934 & 1935 & 1936 & 1937 & 1938 & 1939 & 1940 & 1941 & $194 ?$ & 1943 & 1944 & 1945 & 1946 & $19 \div 7$ & 1918 & $\begin{array}{l}\text { Absolute } \\
\text { increase }\end{array}$ \\
\hline Chicoutimi & $\ldots$ & .70 & .70 & .70 & .70 & .70 & .75 & .80 & .85 & .85 & .85 & .90 & 1,00 & 1.05 & 1.15 & .45 \\
\hline Abitibi * & $\cdots$ & $\cdots$ & $\ldots$ & $\cdots$ & $\ldots$ & $\ldots$ & $\ldots$ & .75 & .75 & .75 & .80 & .80 & 1.00 & 1.05 & 1.15 & .40 \\
\hline Hull & $\ldots$ & .90 & .90 & .90 & 1.00 & 1.00 & 1.00 & 1.00 & 1.00 & 1.05 & 1.05 & 1.15 & 1.25 & 1.25 & 1.25 & .25 \\
\hline Joliette & .60 & .60 & .60 & .60 & .60 & .60 & .60 & .60 & .60 & .65 & .75 & .75 & .85 & .90 & 1.00 & .40 \\
\hline Montréal & .70 & .70 & .70 & .80 & .80 & .80 & .88 & .92 & .97 & .97 & 1.05 & 1.06 & 1.17 & 1.17 & 1.40 & .60 \\
\hline Québec & .70 & .70 & .70 & .75 & .75 & .75 & .80 & .85 & .90 & .90 & 1.00 & 1.00 & 1.10 & 1.15 & 1.20 & .45 \\
\hline Saint-Hyacinthe & $\cdots$ & .50 & .50 & .55 & .65 & .65 & .65 & .70 & .70 & $.771 / 2$ & .85 & .85 & .95 & 1.00 & 1.05 & .40 \\
\hline Saint-Jean & $\cdots$ & $\cdots$ & $\cdots$ & $\cdots$ & .65 & .65 & .70 & .70 & .78 & .78 & .78 & .78 & .88 & .90 & 1.17 & .52 \\
\hline Sherbrooke & .60 & .60 & .60 & .60 & .65 & .65 & .80 & .85 & .85 & .90 & .90 & 1.00 & 1.00 & 1.10 & 1.20 & .55 \\
\hline Drummond $\ddagger$ & $\cdots$ & .55 & .55 & .55 & .60 & .60 & .75 & .75 & .75 & .80 & .80 & .95 & .95 & 1.05 & 1.15 & .55 \\
\hline Sorel & $\cdots$ & $\ldots$ & $\ldots$ & .55 & .60 & .60 & .60 & .60 & .60 & .65 & .75 & .75 & .95 & 1.10 & 1.10 & .50 \\
\hline Terrebonne & $\cdots$ & $\cdots$ & $\cdots$ & $\cdots$ & $\ldots$ & .60 & .75 & .85 & .90 & .90 & .95 & .95 & 1.05 & 1.05 & 1.15 & .55 \\
\hline Trois-Rivières & .70 & .70 & .70 & .70 & .70 & .70 & .80 & .85 & .90 & .95 & .95 & .95 & 1.00 & 1.10 & 1.20 & .50 \\
\hline
\end{tabular}

1 Decrees pursuant to the Collective Agreement Act. In the regions comprising more than one zone the rates mentioned are those of Zone I.

* Subject to a Decree in force in the Chicoutimi region since March 30, 1948.

+ Subject to a Decree in force in the Sherbrooke region (Zone II) from 1936 to 1947 inclusive.

\title{
INDUSTRIAL RELATIONS IN THE ORGANIZED PLANT
}

\author{
W. E. Curky
}

At the outset, mey we say that in presenting our Company's approach to industrial relations, we do not wish to imply that we have reached an advanced degree of perfection or, even of progressiveness, but we do feel that we are on the way. We would like to review some of the activities which we think have been of value to us and discuss briefly our philosophy of industrial relations on which we are basing future plans.

\section{The Problem Defined}

Christian democracy has taught men to aspire toward greater and greater self-realization and self-expression. It has preached the dignity and worth of the individual man. At the same time our present-day mass production society has been reducing the opportunities offered the individual to secure that self-expression. Mass production industry, while creating enormous quantities of goods at low prices, has submerged the individual worker in the flow of production to the point where he is losing, or has lost, all feeling of individual identity, or sense of participation in the enterprise.

It is our belief that the survival of this capitalistic system of ours depends in no small measure on the ability of modern industry to protect the dignity and selfrespect of the ordinary working man. There is no force in society, other than industrial management capable of solving the problem. If we do not succeed the working man will turn out of sheer frustation to another form of society, even though in many ways a less desirable one.

\section{The Search for a Solution}

In seeking an answer in our company, we have put emphasis on the basic atitude of management - of all management - towards the employees generally. Real personnel work is in the last analysis, carried out by the line or the operating organization. If management is genuinely interested in the people it employs and in their progress as individual human beings and makes an effort to express this interest the details will for the most part take care of themselves.

In our view, an Industrial Relations or Personnel Department serves its best purpose in helping to bridge the gap existing between management and labor created by the physical size of modern plants and by mass production factory methods. It is one of the avenues through which management expresses its interest in the employees of the company. 